\title{
Bacteriolysis by Agaricus bisporus
}

\author{
T. R. Fermor, ${ }^{1 *}$ D. A. Wood, ${ }^{1}$ S. P. LinColN ${ }^{1}$ and J. S. FenLon ${ }^{2}$ \\ ${ }^{1}$ Microbiology Department and ${ }^{2}$ Biometrics Department, Institute of Horticultural Research, Littlehampton, \\ West Sussex BN17 6LP, UK
}

(Received 20 June 1990; revised 26 September 1990; accepted 1 October 1990)

\begin{abstract}
Agaricus bisporus, the cultivated mushroom, was able to mineralize dead ${ }^{14} \mathrm{C}$-labelled Bacillus subtilis and utilize the cellular components as sole source of carbon and nitrogen for growth. Consistently higher levels of bacteriolytic activity were obtained when $A$. bisporus was grown on lower concentrations of bacteria, $1.5 \mathrm{mg} \mathrm{ml}^{-1}$ as opposed to $3 \mathrm{mg} \mathrm{ml}^{-1}$ basal liquid medium. A. bisporus also mineralized ${ }^{14} \mathrm{C}$-labelled bacteria in the presence of readily available alternative carbon and nitrogen sources such as glucose and ammonium sulphate. ${ }^{14} \mathrm{C}$-labelled bacteria were degraded to ${ }^{14} \mathrm{CO}_{2}$ more efficiently than $\left[{ }^{14} \mathrm{C}\right]$ cellulose. $\mathrm{A}$. bisporus was able efficiently to mineralize biomass produced in situ ( $>20 \%$ of total label released as ${ }^{14} \mathrm{CO}_{2}$ ) where label was incorporated into the microbial biomass by composting rather than added as killed bacteria. This is the first time that quantitative data have been produced to show that the microbial biomass in wheat straw/animal manure compost might be significant in the nutritional strategy of basidiomycetes.
\end{abstract}

\section{Introduction}

The basic nutritional requirements in vitro of Agaricus bisporus (Lange) Imbach, the cultivated edible mushroom, are known (Wood \& Fermor, 1985). Its commercial production medium, composted wheat straw, is prepared such that it is selective for mushroom mycelial growth. Successful mycelial colonization and subsequent degradation of this medium by $A$. bisporus is dependent on several ecophysiological factors (Wood \& Smith, 1987), but these factors do not completely explain how selectivity can be described in chemical or biological terms (Straatsma et al., 1989).

The linear growth rate of $A$. bisporus in sterilized (autoclaved or irradiated) compost is half of that in unsterilized compost (Fermor et al., 1985). It is apparent, therefore, that micro-organisms or their metabolic products present in compost may be involved in stimulation of mushroom mycelial growth. Electron microscopy has revealed that during composting an amorphous coating builds up on straw in the compost mix (Atkey \& Wood, 1983). This coating contains carbohydrate and phenolic fractions of microbial origin and contains abundant microbial cells, mycelium, spores and debris (Wain, 1981). Some $50 \%$ of this straw coating disappears within one month of the compost being inoculated with $A$. bisporus (Wain, 1981). These observations led to the hypothesis that the microbial biomass accumulated during composting may act as a concentrat- ed nutrient source for the mushroom mycelium as it colonizes the compost. A. bisporus has been shown to degrade and efficiently utilize the biomass of killed bacteria in both solid and liquid media (Fermor \& Wood, 1981), and also to degrade and utilize fungal and actinomycete mycelium (Fermor \& Grant, 1985). The types of lytic enzymes produced by $A$. bisporus which are responsible for this microbial degradation have been analysed (Fermor, 1983; Grant et al., 1984, 1986). They include $\beta$ - $N$-acetylmuramidases and $\beta$ - $N$-acetylglucosaminidases.

A range of actively growing bacteria stimulate mushroom mycelial extension on compost malt agar medium (Rainey, 1989). Similarly, A. bisporus, Coprinus quadrifidus, Lepista nuda and Pleurotus ostreatus are able to attack and digest live microcolonies of bacteria (Barron, 1988). In co-cultures these fungi show particular sensitivity to the presence of bacterial colonies and develop specialized directional hyphae terminating in haustorium-like, absorptive hyphae which penetrate the bacterial microcolonies (Barron, 1988). Mycelial growth of $\boldsymbol{A}$. bisporus on sterilized compost is greatly stimulated by pre-incubating the compost with the thermophilic fungus Scytalidium thermophilum, and mushroom fruitbody yield was positively correlated with the $S$. thermophilum biomass (Straatsma et al., 1989). It has been shown that the most favourable temperature for compost degradation is $50-55^{\circ} \mathrm{C}$, whilst $40-45^{\circ} \mathrm{C}$ is the optimum temperature for removal of ammonia from 
compost, and that thermophilic fungi are most important in this process (Ross \& Harris, 1983).

The total microbial biomass in a horse manure/wheat straw compost (after $14 \mathrm{~d}$ composting), estimated by both direct counts and biochemical methods, was $9.2 \mathrm{mg}$ carbon (g dry wt compost) ${ }^{-1}$ (Sparling et al., 1982). This represented approximately $2 \%$ of the compost dry weight assuming that microbial biomass contains $50 \%(\mathrm{w} / \mathrm{w})$ carbon. The studies reported here were designed to determine whether $\boldsymbol{A}$. bisporus was able to degrade and utilize live or killed microbial biomass in compost in the presence of alternative carbon and nitrogen sources. This was examined by monitoring the biodegradation of radiolabelled bacterial biomass produced in vitro or by producing radiolabelled microbial biomass in vivo by the use of a bench-scale composting unit.

\section{Methods}

Organisms. Agaricus bisporus D621 was used. This is a heterokaryotic fertile strain of commercial origin obtained from the IHR (Littlehampton) collection of basidiomycete fungi. Bacillus subtilis 168 derivative S2861 (trivial name 261) spollA69 spoG55 rif-2 (asporogenous) was obtained from the National Institute for Medical Research, London, UK. This sporeless mutant was used to avoid the practical hazards associated with growing a spore-forming bacterium in a large-scale fermenter facility.

Basic medium for growth of $B$. subtilis $168 \mathrm{~A} . \mathrm{B}$. subtilis was grown in basal Spizizen Salts Medium (SSM ; Piggot, 1975) which contained: $\left(\mathrm{NH}_{4}\right)_{2} \mathrm{SO}_{4}, 2 \mathrm{~g} ; \mathrm{K}_{2} \mathrm{HPO}_{4}, 14 \mathrm{~g} ; \mathrm{KH}_{2} \mathrm{PO}_{4}, 6 \mathrm{~g}$; trisodium citrate $2 \mathrm{H}_{2} \mathrm{O}, 1 \mathrm{~g} ; \mathrm{MgSO}_{4} .7 \mathrm{H}_{2} \mathrm{O}, 0.2 \mathrm{~g}$ in $900 \mathrm{ml}$ sterile distilled water. Bacto Casamino acids (1.0 g, Difco, Technical 0231-02) containing $8 \%$ (w/w) total $\mathrm{N}$ was added to the medium, which was autoclaved at $121^{\circ} \mathrm{C}$ for $15 \mathrm{~min}$. D-Glucose $(100 \mathrm{ml})$ was filter-sterilized (Millipore, $0.22 \mu \mathrm{m})$ and added to the cooled medium to give a final concentration of $0.5 \%(\mathrm{w} / \mathrm{v})$.

Preliminary experiment. Production of ${ }^{14} \mathrm{C}$-labelled bacteria. A preliminary experiment was undertaken to determine which concentration of Casamino acids (a readily available nutrient source) gave the most efficient uptake of ${ }^{14} \mathrm{C}$-labelled protein hydrolysate, and a satisfactory yield of microbial biomass.

Medium. Each Erlenmeyer flask $(100 \mathrm{ml})$ contained SSM $(9 \mathrm{ml})$, Dglucose $[1 \mathrm{ml}$, to give a final concentration in medium of $0.5 \%(\mathrm{w} / \mathrm{v})]$ and vitamin-free Casamino acids $(1,10,50$ or $100 \mathrm{mg}$; Difco). There were two flasks for each of the four concentrations of Casamino acids. [U- $\left.{ }^{14} \mathrm{C}\right]$ Protein hydrolysate (Amersham) was added to sterile distilled water $\left(1.25 \mu \mathrm{Ci} \mathrm{ml}^{-1}\right)$ and $1 \mathrm{ml}$ of this diluted hydrolysate was added to each of the eight flasks.

Counting ${ }^{14}$ C uptake by B. subtilis. After shaking, a sample of the initial medium ( $1 \mathrm{ml}$ ) was removed from each flask and placed into PCS liquid scintillation fluid $(10 \mathrm{ml}$, Amersham) to count the total radioactivity in each flask prior to inoculation with bacteria. The eight flasks were then inoculated with $0.2 \mathrm{ml} \mathrm{B}$. subtilis $\left(10^{10}\right.$ c.f.u. $\left.\mathrm{ml}^{-1}\right)$, incubated at $37^{\circ} \mathrm{C}$ and shaken at 150 r.p.m. Bacterial growth in these flasks was estimated by measuring the $\mathrm{OD}_{600}$ of $B$. subtilis growing under identical conditions in four control flasks containing the same media minus $\left[\mathrm{U}^{-14} \mathrm{C}\right]$ protein hydrolysate. The bacteria in flasks containing 10 or $5 \mu \mathrm{g}$ Casamino acids $\mathrm{l}^{-1}$ were harvested after $4.75 \mathrm{~h}$ and those in flasks containing 1 or $0.1 \mu \mathrm{g}$ Casamino acids $\mathrm{l}^{-1}$ after $6 \cdot 25 \mathrm{~h}$.

The following counts of radioactivity were made on samples of bacterial culture from replicate flasks containing each of the four concentrations of Casamino acids. (i) Total ${ }^{14} \mathrm{C}$ present in bacteria plus medium. A sample ( $1 \mathrm{ml}$ ) was placed into $10 \mathrm{ml}$ PCS counting fluid. (ii) ${ }^{14} \mathrm{C}$ present in bacteria. Bacteria in liquid culture $(2 \mathrm{ml})$ were added to ice-cold trichloroacetic acid $[2 \mathrm{ml}, 10 \%(\mathrm{w} / \mathrm{v})]$, mixed rapidly and filtered (Whatman GF/C, $2.5 \mathrm{~cm}$ ). The bacterial precipitate was washed thoroughly with sterile distilled water and vacuum dried for $16 \mathrm{~h}$ at $100^{\circ} \mathrm{C}$ and weighed. Dried bacteria and glass fibre filter disc were then added to $10 \mathrm{ml}$ PCS counting fluid. (iii) The initial filtrates $(1 \mathrm{ml})$ from the cultures were also added to $10 \mathrm{ml}$ PCS counting fluid. From these counts it was then possible to calculate the percentage of the initial ${ }^{14} \mathrm{C}$ added which had been taken up by the $B$. subtilis cells.

Growth of A. bisporus on ${ }^{14} \mathrm{C}$-labelled killed bacteria as sole carbon and nitrogen source. ${ }^{14} \mathrm{C}$-labelled $B$. subtilis cells were produced and added to unlabelled $B$. subtilis cells. These bacterial cells were then the sole carbon and nitrogen source in the medium used to grow $A$. bisporus.

Production of ${ }^{14} \mathrm{C}$-labelled $B$. subtilis. The bacteria were grown in five flasks $(10 \mathrm{ml})$ each containing SSM $(9 \mathrm{ml}), \mathrm{D}-$ glucose $(5 \%, \mathrm{w} / \mathrm{v}, 1 \mathrm{ml})$ and Casamino acids $(10 \mathrm{mg}) .\left[\mathrm{U}-{ }^{14} \mathrm{C}\right]$ Protein hydrolysate $(0.2 \mathrm{ml}$, $10 \mu \mathrm{Ci})$ was diluted in sterile distilled water $(4.8 \mathrm{ml})$ and $1 \mathrm{ml}$ was then added to each flask. Each flask was then inoculated with $0.2 \mathrm{ml} B$. subtilis $\left(10^{7}\right.$ c.f.u. $\left.\mathrm{ml}^{-1}\right)$. The cultures were incubated for $6.5 \mathrm{~h}$ at $37^{\circ} \mathrm{C}$ and shaken at 150 r.p.m. The harvested cells $\left(\mathrm{OD}_{600} 0.603\right)$ were then killed by suspension in $10 \%(\mathrm{w} / \mathrm{v})$ trichloroacetic acid (TCA).

Production of unlabelled $B$. subtilis. A modified basic medium for growth of $B$. subtilis was used containing $0.5 \%$ Casamino acids, as this gave the greatest biomass yield. The medium $(81)$ was autoclaved at $121^{\circ} \mathrm{C}$ for $40 \mathrm{~min}$ in a fermenter. The medium was inoculated with $100 \mathrm{ml} \mathrm{B}$. subtilis $\left(10^{7}\right.$ c.f.u. $\mathrm{ml}^{-1}$, grown on basic medium $)$ and incubated with continuous aeration $\left(101 \mathrm{~min}^{-1}\right.$ at $37^{\circ} \mathrm{C}$ for $\left.12 \mathrm{~h}\right)$. The cells $\left(\mathrm{OD}_{600} 0.720\right)$ were harvested by centrifugation (MSE 18, 10000 r.p.m.). The $B$. subtilis cell paste was then suspended in $100 \mathrm{ml}$ sterile distilled water to which was added $100 \mathrm{ml} \mathrm{TCA}(20 \%, \mathrm{w} / \mathrm{v})$. A second batch culture of $B$. subtilis was produced under identical conditions.

Use of the bacterial cells in growth experiments. The harvested cells were treated as follows: (i) ${ }^{14} \mathrm{C}$-labelled $B$. subtilis in $50 \mathrm{ml} \mathrm{TCA}(10 \%$, $\mathrm{w} / \mathrm{v})$ were added to unlabelled $B$. subtilis in $200 \mathrm{ml} \mathrm{TCA}(10 \%$, w/v); (ii) the mixture was stirred at 100 r.p.m. for $30 \mathrm{~min}$, then (iii) centrifuged $(12000 \mathrm{~g}, 15 \mathrm{~min})$ to remove most of the TCA, and (iv) washed three times in copious distilled water; (v) cells were resuspended in sterile distilled water at $15 \mathrm{mg} \mathrm{ml}^{-1}$; (vi) a sample of the suspended cells was then digested $[0.2 \mathrm{ml}$ in $1 \mathrm{ml} \mathrm{NCS}$ tissue solubilizer (Amersham)] at $50{ }^{\circ} \mathrm{C}$ for $12 \mathrm{~h}$ and radioactivity counted using a Beckman LC 7800 liquid scintillation counter, which corrects for quenching by external standards.

Into each of three flasks $(100 \mathrm{ml})$ were dispensed $2 \mathrm{ml}$ acid-killed ${ }^{14}$ C-labelled B. subtilis suspension $(250000$ d.p.m. $)$ and $6.6 \mathrm{ml}$ basal salts; these were autoclaved for $15 \mathrm{~min}$ at $121^{\circ} \mathrm{C}$. Basal salts (Treschow, 1944) contained: $\mathrm{KCl}, 0 \cdot 2 \mathrm{~g} ; \mathrm{MgSO}_{4} .7 \mathrm{H}_{2} \mathrm{O}, 0 \cdot 2 \mathrm{~g} ; \mathrm{CaCl}_{2}$, $0.2 \mathrm{~g} ; \mathrm{FeCl}_{3} .6 \mathrm{H}_{2} \mathrm{O}, 10 \mathrm{mg}$; and trace elements $\mathrm{H}_{3} \mathrm{BO}_{3}, 0.3 \mathrm{mg}$; $\mathrm{CuSO}_{4} .5 \mathrm{H}_{2} \mathrm{O}, 0.25 \mathrm{mg} ; \mathrm{MnCl}_{2} .4 \mathrm{H}_{2} \mathrm{O}, 2 \mathrm{mg} ; \mathrm{Na}_{2} \mathrm{MoO}_{4} .7 \mathrm{H}_{2} \mathrm{O}$, $0.4 \mathrm{mg} ; \mathrm{ZnSO}_{4} \cdot 7 \mathrm{H}_{2} \mathrm{O}, 0 \cdot 2 \mathrm{mg} ; \mathrm{CoCl}_{2} .6 \mathrm{H}_{2} \mathrm{O}, 0.7 \mathrm{mg}$; distilled water to $659 \mathrm{ml}$. Phosphate buffers $\mathrm{Na}_{2} \mathrm{HPO}_{4} \cdot 2 \mathrm{H}_{2} \mathrm{O}(750 \mu \mathrm{l}$; stock solution $\left.15 \mathrm{~g} \mathrm{l}^{-1}\right)$ and $\mathrm{KH}_{2} \mathrm{PO}_{4}\left(150 \mu \mathrm{l}\right.$; stock solution $\left.9 \mathrm{~g} \mathrm{l}^{-1}\right)$ were added to the flasks after autoclaving separately. Vitamin solution $(20 \mathrm{mg}$ thiamin. $\mathrm{HCl}$ and $2 \mathrm{mg}$ biotin in $100 \mathrm{ml}$ distilled water) was sterilized by membrane filtration (Millipore $0.22 \mu \mathrm{m}$ ) and $10 \mu \mathrm{l}$ was added to each flask which was then inoculated with $0.5 \mathrm{ml}$ A. bisporus D621 mycelial suspension (Fermor \& Wood, 1981). Each flask was then incubated at $25^{\circ} \mathrm{C}$ for $56 \mathrm{~d}$, and ${ }^{14} \mathrm{CO}_{2}$ evolved was monitored. 
Growth of $A$. bisporus on ${ }^{14} \mathrm{C}$-labelled killed bacteria with an additional carbon and nitrogen source. Ammonium sulphate was added to cultures together with glucose or cellulose. Experiments were again conducted with $10 \mathrm{ml}$ cultures in $100 \mathrm{ml}$ Erlenmeyer flasks. Twelve flasks contained the following medium: basal salts $(6.6 \mathrm{ml}),{ }^{14} \mathrm{C}$-labelled $B$ subtilis suspension in sterile distilled water $(1 \mathrm{ml}, 140000$ d.p.m.), and autoclaved at $121{ }^{\circ} \mathrm{C}$ for $15 \mathrm{~min}$. Sterile phosphate buffers $(0.9 \mathrm{ml})$ and vitamin solution $(10 \mu \mathrm{l})$ were then added to each flask before inoculation with $0.5 \mathrm{ml}$ A. bisporus D621 mycelial suspension in sterile distilled water. The flasks were divided into three groups of four and the following supplements added to each group. (1) Distilled water (1 ml). (2) D-Glucose $(18.75 \mathrm{mg}$ in $0.5 \mathrm{ml})$ and ammonium sulphate $(10.6 \mathrm{mg}$ in $0.5 \mathrm{ml})$ sterilized separately by membrane filtration (Millipore $0.22 \mu \mathrm{m})$. The ${ }^{14} \mathrm{C}$-labelled bacterial suspension $(1 \mathrm{ml})$ contained $15 \mathrm{mg}$ dry wt bacteria. Assuming dry $B$. subtilis cells contain $50 \%$ by weight carbon and $15 \%$ by weight nitrogen (Jenkinson, 1981), then the $1 \mathrm{ml}$ suspension contains $7.5 \mathrm{mg}$ carbon and $2.25 \mathrm{mg}$ nitrogen. Additional carbon and nitrogen supplements in these four flasks were calculated to give equal $\mathrm{C}$ and $\mathrm{N}$ to that of the bacteria already in the flask. (3) Distilled water $(0.5 \mathrm{ml})$, cellulose $(18.75 \mathrm{mg}$, Whatman CC41 powder) and ammonium sulphate $(10.6 \mathrm{mg}$ in $0.5 \mathrm{ml})$. All the flasks were incubated at $25^{\circ} \mathrm{C}$ for $49 \mathrm{~d}$ and ${ }^{14} \mathrm{CO}_{2}$ evolved was monitored.

Growth of A. bisporus on ${ }^{14} \mathrm{C}$-labelled glucose and cellulose. A similar set of 12 flasks containing basal salts $(6.6 \mathrm{ml})$ was set up. After autoclaving at $121{ }^{\circ} \mathrm{C}$ for $15 \mathrm{~min}$, to each was added sterile phosphate buffers $(0.9 \mathrm{ml})$ and vitamin solution $(10 \mu \mathrm{l})$ prior to inoculation with $0.5 \mathrm{ml}$ A. bisporus D62l mycelial suspension. The flasks were divided into three groups of four replicates and to each group was added: (1) ${ }^{14} \mathrm{C}$-labelled bacterial suspension $(1 \mathrm{ml}, 120000$ d.p.m. $)$ and distilled water $(1 \mathrm{ml})$, or (2) unlabelled B. subtilis $(15 \mathrm{mg})$, distilled water $(1 \mathrm{ml})$, ammonium sulphate $(10.6 \mathrm{mg}$ in $0.5 \mathrm{ml}$ distilled water), D-glucose $\left(18.75 \mathrm{mg}\right.$ in $0.5 \mathrm{ml}$ distilled water) and D-[U- $\left.{ }^{14} \mathrm{C}\right] \mathrm{glucose}(10 \mu \mathrm{l}, 40000$ d.p.m., Amersham), or (3) unlabelled B. subtilis $(15 \mathrm{mg})$, distilled water (1 $\mathrm{ml})$, ammonium sulphate ( $10.6 \mathrm{mg}$ in $0.5 \mathrm{ml}$ distilled water), cellulose (18.75 mg, Whatman CC4l powder) and diluted aqueous suspension of $\left[{ }^{4} \mathrm{C}\right]$ cellulose $[0.5 \mathrm{ml}, 44000$ d.p.m.; (Cellulose(2-C14), ICN Pharmaceuticals; sp. act. $\left.3.4 \mu \mathrm{Ci} \mathrm{mg}{ }^{-1}\right)$ ]. All cultures were incubated at $25^{\circ} \mathrm{C}$ for $51 \mathrm{~d}$, and ${ }^{14} \mathrm{CO}$, evolved was monitored.

Degradation of killed bacteria in compost. Twelve $100 \mathrm{ml}$ Erlenmeyer flasks were filled with $7 \mathrm{~g}$ (fresh wt: moisture content $70 \%, \mathrm{pH} 7.0$ ) of GCRI Formula 2 wheat straw/chicken manure compost (Randle, 1974) taken at the end of the second and final phase of composting. Four of the flasks were then sterilized at $121{ }^{\circ} \mathrm{C}$ for $20 \mathrm{~min}$ on each of two successive days. Sterile ${ }^{14} \mathrm{C}$-labelled $B$. subtilis suspension $(0.9 \mathrm{ml}$, 126000 d.p.m.) was then carefully pipetted, to ensure optimal mixing, into all the flasks containing compost. The experiment consisted of three treatments each with four replicates as follows. (1) Six sterile wheat grains were transferred aseptically to unsterile compost and added bacteria suspension. This culture acted as a control to determine how readily the natural compost microflora could degrade the incorporated ${ }^{14} \mathrm{C}$-labelled bacteria; (2) Six grains of $A$. hisporus D621 mushroom spawn were added to bacterial suspension and unsterile compost; (3) Six grains of $A$. bisporus D621 mushroom spawn were added to bacterial suspension and sterile compost. The spawn was prepared using wheat grains as described by Elliott (1985). The cultures were incubated at $25^{\circ} \mathrm{C}$ for $36 \mathrm{~d}$ and ${ }^{14} \mathrm{CO}_{2}$ evolved was monitored.

Growth of A. bisporus on ${ }^{14} \mathrm{C}$-labelled compost. Three separate batches of compost were prepared, each containing: $100 \mathrm{~g}$ wheat straw cv. Sentry (moisture content $15 \%, \mathrm{~N}$ content $0.42 \%$ dry wt), $1.9 \mathrm{~g}$ $\mathrm{H}_{2}$ N.CO. $\mathrm{NH}_{2}$ (urea), $2.5 \mathrm{~g}$ D-glucose and $3.0 \mathrm{~g} \mathrm{CaSO}_{4}$ (gypsum, agricultural grade). The straw was chopped into $1-2 \mathrm{~cm}$ lengths and soaked in water for $12 \mathrm{~h}$. Excess water was strained off and the straw reweighed. The urea, D-glucose and gypsum were then thoroughly mixed in $75 \mathrm{ml}$ water. This liquid was then carefully mixed with $175 \mathrm{~g}$ of the wet straw. The moisture content of this mixture was $65 \%$. To one of the three compost batches was also added $0.4 \mathrm{ml}\left[{ }^{14} \mathrm{C}\right]$ protein hydrolysate $(20 \mu \mathrm{Ci}$, Amersham $)$; this was incorporated with the urea, D-glucose, gypsum liquid mixture

The compost mixes were placed into each of three 21 multi-adaptor flasks for controlled environment composting (Smith \& Wood, 1990). Each flask was then inoculated with $0.5 \mathrm{~g}$ GCRI Formula 2 compost to act as a balanced microbial starter culture. The flasks were suspended in water baths at $50^{\circ} \mathrm{C}$. The composts were aerated with humidified air (flow rate $10 \mathrm{~h} \mathrm{~h}^{-1}$ ) for $2 \mathrm{~min}$ in every $5 \mathrm{~min}$ to give an air change of $4 \mathrm{l} \mathrm{h}^{-1}$ per flask. Two $\mathrm{CO}_{2}$-trapping towers were placed in series on the outlet from the compost flask containing ${ }^{14} \mathrm{C}$. The towers each contained $320 \mathrm{ml}$ methanol and $80 \mathrm{ml}$ ethanolamine; these solvents were renewed every $4 \mathrm{~d}$ and the entrapped ${ }^{14} \mathrm{CO}_{2}$ counted. Methanol/ ethanolamine ${ }^{14} \mathrm{CO}_{2}$-trapping solvents $(5 \mathrm{ml})$ were added to scintillation vials containing $5 \mathrm{ml}$ of the remaining three components of scintillation fluid [toluene plus $4 \mathrm{~g}$ PPO (1 toluene) $)^{-1}$ and $0.1 \mathrm{~g}$ POPOP (l toluene $)^{-1}$; Kirk et al., 1975].

After $21 \mathrm{~d}$ compost preparation was complete; three samples $(1 \mathrm{~g}$, fresh wt) of compost were taken and their radioactivity determined by combustion using a carbon-hydrogen analyser (Biological Oxidizer OX300, Laboratory Impex). ${ }^{14} \mathrm{C}$-labelled compost $(2.5 \mathrm{~g}$ fresh $\mathrm{wt}$, 50000 d.p.m.) was then thoroughly mixed with $7.5 \mathrm{~g}$ unlabelled compost for each of 24 Erlenmeyer flasks $(100 \mathrm{ml})$. The experimental treatments were as follows: (1) $10 \mathrm{~g}$ unsterile compost was inoculated with six grains of $\boldsymbol{A}$. bisporus D621 spawn (10 replicates); (2) as treatment (1) but using six sterile wheat grains instead of spawn (6 replicates); (3) $10 \mathrm{~g}$ compost having been autoclaved on two consecutive days at $121^{\circ} \mathrm{C}$ for $15 \mathrm{~min}$, inoculated with six grains of spawn $(6$ replicates); and (4) as treatment (3) but using six sterile wheat grains instead of spawn (2 replicates) to monitor aseptic technique. For comparison, four flasks each of sterile and unsterile non-radioactive composts were each inoculated with six grains of $A$. bisporus spawn. The surface of the compressed compost in the flasks was covered by a glass microfibre filter (Whatman GF/C, $4.7 \mathrm{~cm}$ ). These filter papers were wetted at weekly intervals (for the first 2 months and less frequently thereafter) with $1 \mathrm{ml}$ steriled distilled water to ensure that the compost remained moist. The flasks were incubated at $25{ }^{\circ} \mathrm{C}$ for $137 \mathrm{~d}$. The flasks were flushed twice weekly with air and the ${ }^{14} \mathrm{CO}_{2}$ accumulated was monitored.

Radiorespirometry. Biodegradation of ${ }^{14} \mathrm{C}$-radiolabelled material by A. bisporus was determined by monitoring the formation of ${ }^{14} \mathrm{CO}_{2}$. The apparatus was based upon that described by Kirk et al. (1978), with $10 \mathrm{ml}$ cultures in $100 \mathrm{ml}$ Erlenmeyer flasks. The flasks were fitted with butyl rubber stoppers through which two $6 \mathrm{~mm}$ glass tubes were inserted. One of these tubes extended into the flask within $1 \mathrm{~cm}$ of the culture medium; outside the flask it was connected via rubber tubing to a sterilizing filter. The second glass tube extended $1 \mathrm{~cm}$ or less into the flask, and the outside was connected via rubber tubing to a $3 \mathrm{~cm} 180$ gauge Luer-type needle. Clamps on both the rubber tubings allowed the flasks to be closed. The following modifications to the original apparatus design of Kirk were made. (i) All tubing was Butyl-XX (Esco Rubber, UK), $1.6 \mathrm{~mm}$ wall $\times 5 \mathrm{~mm}$ bore. This was found to be less permeable to $\mathrm{CO}_{2}$ than natural or silicone rubber and withstood repeated autoclaving. (ii) $37 \mathrm{~mm}$ bacterial air vents (Gelman Sciences) were incorporated into both inlet and outlet lines of each flask to maintain sterility over long periods. (iii) Hoffman clamps were replaced by polypropylene quick release clamps (Gallenkamp, UK). Flasks were flushed every 3-4 $\mathrm{d}$ by opening the clamps and forcing air through the filters at $100-200 \mathrm{ml} \mathrm{min}^{-1}$ for $15 \mathrm{~min}$. This was found to remove all the evolved ${ }^{14} \mathrm{CO}_{2}$, which was trapped by placing the Luertype needle on the end of the flask exit line in $10 \mathrm{ml}$ of an ethanolaminecontaining scintillation fluid (Kirk et al., 1975) in a $20 \mathrm{ml}$ scintillation 
vial. Studies showed that ${ }^{14} \mathrm{CO}_{2}$ trapping was $>98 \%$ efficient. The flask closures fitted with flushing ports and the apparatus used to flush the $A$. bisporus culture head space and trap the evolved ${ }^{14} \mathrm{CO}_{2}$ have been illustrated by Roberts (1985). All radioactivity measurements were made in a Beckman LC 7800 liquid scintillation counter with quench correction by external standards.

\section{Results}

The Casamino acids concentration in basic salts medium was found to have a considerable effect on the efficiency of incorporation of ${ }^{14} \mathrm{C}$ by $B$. subtilis from [U-14 $\mathrm{C}$ ]protein hydrolysate (Table 1). It was decided to use $1 \mathrm{mg} 0 \cdot 1 \%$ $(\mathrm{w} / \mathrm{v})$ Casamino acids $\mathrm{ml}^{-1}$ in the subsequent experiments as this concentration gave the most efficient uptake of the radiolabel, whilst producing adequate bacterial biomass.

Results from experiments to demonstrate bacteriolysis by $A$. bisporus were subjected to statistical analysis. Plots of cumulative percentage degradation against time showed sigmoid-shaped responses. In most instances the curves were asymmetric, with a rapid exponential phase followed by a slower deceleration phase prior to approaching a limiting value by about day 50 .

Cumulative count data are not amenable to the usual methods of least squares (Brain \& Butler, 1988), primarily because successive count values are not independent but are increasingly dependent on previous counts. There are two aspects to most of the data sets reported here: the proportion of labelled $\mathrm{C}$ that has degraded, and the nature of the response of that which was degraded. The former statistics can be estimated either as the proportion of labelled $\mathrm{C}$ degraded on the last day of sampling, or can be determined by fitting an empirical distribution function (in most instances the lognormal) to the data and estimating the limiting proportion (Brain \& Butler, 1988). In examining the nature of the degradation response it is useful to consider the time to a specific level of degradation; thus useful summary statistics are the median (time to $50 \%$ degradation), and the inter-quartile range (time from $25 \%$ to $75 \%$ degradation). This latter statistic can be thought of as a sort of slope, defining the rate of degradation. These statistics obviously only apply to the proportion of labelled isotope that was degraded. Fig. 1 gives a simple visual interpretation.

By considering the data in uncumulated form, i.e. as a frequency table of counts between given time intervals, a mean time to degradation can also be calculated. The asymmetric nature of most of the sigmoid responses

Table 1. Effect of Casamino acids concentration in SSM basic salts medium on uptake of ${ }^{14} \mathrm{C}$ by B. subtilis from $\left[U-1{ }^{14} \mathrm{C}\right.$ protein hydrolysate

\begin{tabular}{|c|c|c|c|c|c|}
\hline \multirow[b]{2}{*}{$\begin{array}{c}\text { Casamino } \\
\text { acids } \\
\left(\mu \mathrm{g} \mathrm{l}^{-1}\right)\end{array}$} & \multirow{2}{*}{$\begin{array}{c}10^{-3} \times \text { Radioactivity } \\
\text { in basic } \\
\text { medium before } \\
\text { inoculation (d.p.m.) }\end{array}$} & \multicolumn{4}{|c|}{ Harvested B. subtilis } \\
\hline & & $\begin{array}{l}\text { Time after } \\
\text { inoculation } \\
\text { (h) }\end{array}$ & $\begin{array}{l}\text { Culture } \\
\mathrm{OD}_{600}\end{array}$ & $\begin{array}{l}\text { Bacterial } \\
\text { dry wt } \\
\text { (mg) }\end{array}$ & $\begin{array}{l}\text { Radioactivity } \\
\text { [d.p.m. }(\mu \mathrm{g} \mathrm{dry} \text { wt } \\
\text { bacteria })^{-1} \text { ] }\end{array}$ \\
\hline 10 & 285 & 4.75 & 1.080 & 4.80 & 14.7 \\
\hline 5 & 310 & 4.75 & 0.929 & 4.00 & $23 \cdot 7$ \\
\hline 1 & 322 & $6 \cdot 25$ & 0.703 & $2 \cdot 81$ & $56 \cdot 6$ \\
\hline $0 \cdot 1$ & 313 & $6 \cdot 25$ & $0 \cdot 343$ & 1.26 & $123 \cdot 3$ \\
\hline
\end{tabular}

Table 2. Degradation by A. bisporus of killed ${ }^{14} \mathrm{C}$-labelled $B$. subtilis acting as sole carbon and nitrogen source in Treschow's basal salts liquid medium

Sample statistics for time to degradation (d) of labelled bacteria in individual flasks.

\begin{tabular}{|c|c|c|c|c|c|c|c|}
\hline \multirow{2}{*}{$\begin{array}{c}\text { Sample } \\
\text { no. }\end{array}$} & \multirow[b]{2}{*}{ Mean } & \multirow[b]{2}{*}{ Median } & \multicolumn{2}{|c|}{ Quartile } & \multirow{2}{*}{$\begin{array}{l}\text { Inter- } \\
\text { quartile } \\
\text { range }\end{array}$} & \multicolumn{2}{|c|}{$\begin{array}{l}\text { Percentage } \\
\text { degradation }\end{array}$} \\
\hline & & & Lower & Upper & & Day 56 & Limiting \\
\hline 1 & 26.5 & $24 \cdot 7$ & \multicolumn{2}{|c|}{$20 \cdot 6-31 \cdot 6$} & $11 \cdot 0$ & $48 \cdot 7$ & $48 \cdot 7$ \\
\hline 2 & $29 \cdot 3$ & $29 \cdot 1$ & \multicolumn{2}{|c|}{$23 \cdot 6-34.8$} & $11 \cdot 2$ & $51 \cdot 7$ & 51.8 \\
\hline 3 & $24 \cdot 0$ & $21 \cdot 7$ & \multicolumn{2}{|c|}{$17 \cdot 4-29 \cdot 3$} & 11.9 & $37 \cdot 1$ & $37 \cdot 1$ \\
\hline Mean & $26 \cdot 6$ & $25 \cdot 2$ & \multicolumn{2}{|c|}{$20 \cdot 5-31 \cdot 9$} & $11 \cdot 4$ & $45 \cdot 8$ & $45 \cdot 9$ \\
\hline SEM & 1.53 & $2 \cdot 15$ & 1.79 & 1.59 & 0.27 & $4 \cdot 45$ & 4.47 \\
\hline
\end{tabular}

SEM, standard error of the mean.

* Limiting percentage degradation estimated from fitted lognormal distribution. 


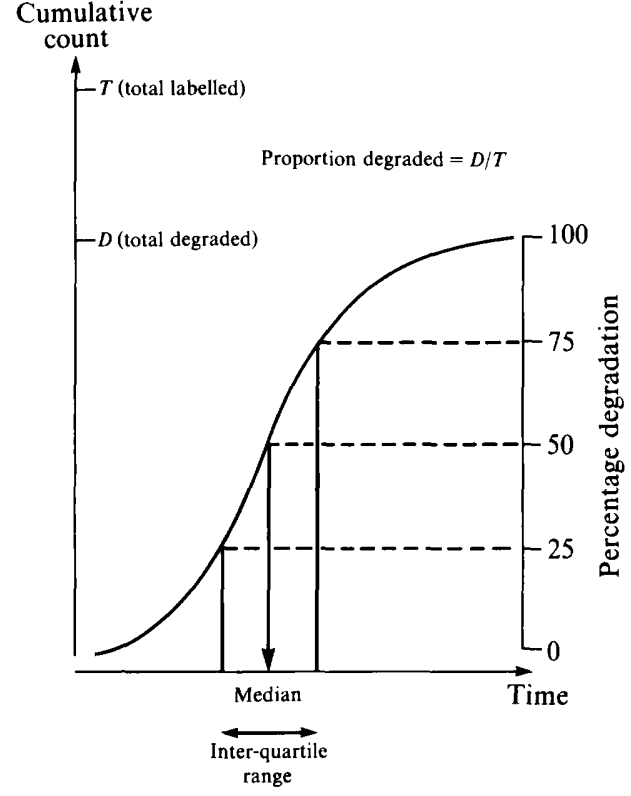

Fig. 1. Determination of median and inter-quartile range from cumulative degradation response.

meant that means determined on logarithmically-transformed data were more compatible with the median; consequently such means have been used throughout.

In the experiments reported here, summary statistics were calculated for each replicate using the statistical program MLP (Ross, 1987), and these values were then analysed by analysis of variance. Mean values are presented for experimental treatments (where appropriate) together with standard errors of differences between means (SEDs).

$A$ bisporus was able to mineralize dead ${ }^{14} \mathrm{C}$-labelled bacteria and utilize their cellular components as a sole source of carbon and nitrogen for growth (Table 2). These results confirm the earlier findings of Fermor \& Wood (1981) and Grant et al. (1984) that A. bisporus produces a set of enzymes capable of efficiently utilizing the complex of bacterial polymers. The ${ }^{14} \mathrm{C}$ label was partitioned at the end of the experiment as follows: ${ }^{14} \mathrm{CO}_{2}$ evolved $\left(45.8 \%\right.$ of total ${ }^{14} \mathrm{C}$ added), culture supernatant liquid $(26.6 \%)$, microbial mat consisting of mushroom mycelium and undegraded bacteria $(27.6 \%)$. Plots of cumulative percentage degradation against time showed a sigmoid-shaped response. In this experiment there was a symmetrical degradation response with the median and mean values quite close together (Table 2). By day 56 degradation had virtually ceased, with an average of $45.8 \%$ of labelled carbon collected.

Consistently higher bacteriolytic activities were obtained when $A$. bisporus was grown on lower concentrations of bacteria. On media containing $1.5 \mathrm{mg}$ bacteria $\mathrm{ml}^{-1}$ the mean cumulative degradation was $64.9 \%$ after $56 \mathrm{~d}$ (Table 3), whereas on media containing $3.0 \mathrm{mg}$ bacteria $\mathrm{ml}^{-1}$ the cumulative degradation was only $45.8 \%$ over the same time period (Table 2 ). The most notable feature of the data from the experiment in Table 3 was the impact of one of the control samples: exclusion of this sample from the analysis causes most of the differences between treatments to be statistically significant. The sample was markedly different from the other three controls in that only $30.9 \%$ of the labelled $\mathrm{C}$ had degraded by day 49 compared with a mean of $64.9 \%$ for the others. We can offer no explanation as to why this marked difference occurred. Analysis of the data excluding this sample showed several significant fea-

Table 3. Degradation by A. bisporus of killed ${ }^{14} \mathrm{C}$-labelled $B$. subtilis used as sole carbon and nitrogen source (control), with added glucose, or with added cellulose in Treschow's basal salts liquid medium

Values for time to degradation (presented in d) are means of four replicate samples for each treatment.

\begin{tabular}{|c|c|c|c|c|c|c|}
\hline \multirow[b]{2}{*}{ Treatment } & \multirow[b]{2}{*}{ Mean } & \multirow[b]{2}{*}{ Median } & \multirow{2}{*}{$\begin{array}{l}\text { Lower } \\
\text { quartile }\end{array}$} & \multirow{2}{*}{$\begin{array}{l}\text { Inter- } \\
\text { quartile } \\
\text { range }\end{array}$} & \multicolumn{2}{|c|}{$\begin{array}{l}\text { Percentage } \\
\text { degradation }\end{array}$} \\
\hline & & & & & Day 56 & Limiting \\
\hline \multicolumn{7}{|l|}{${ }^{14} \mathrm{C}$-Bacteria } \\
\hline (control) & $16 \cdot 5$ & $16 \cdot 5$ & $12 \cdot 2$ & 11.6 & $56 \cdot 4$ & $59 \cdot 0$ \\
\hline (excluding 1 value & $17 \cdot 6$ & $17 \cdot 7$ & $13 \cdot 4$ & 11.8 & 64.9 & $68 \cdot 1)$ \\
\hline \\
\hline \multicolumn{7}{|l|}{${ }^{14} \mathrm{C}$-Bacteria + } \\
\hline cellulose & $15 \cdot 3$ & $15 \cdot 3$ & 11.6 & $10 \cdot 7$ & $48 \cdot 8$ & $50 \cdot 8$ \\
\hline $\begin{array}{l}\text { SED }(9 \text { d.f.) } \\
\text { (excluding } 1 \text { value }\end{array}$ & $\begin{array}{l}1 \cdot 12 \\
0.64\end{array}$ & $\begin{array}{l}1.37 \\
1.00\end{array}$ & $\begin{array}{l}1 \cdot 05 \\
0.51\end{array}$ & $\begin{array}{l}1.40 \\
1.47\end{array}$ & $\begin{array}{l}8 \cdot 46 \\
5 \cdot 11\end{array}$ & $\begin{array}{l}8 \cdot 61 \\
4 \cdot 67)\end{array}$ \\
\hline \multirow{2}{*}{$\begin{array}{l}\text { Significance } \dagger \\
\text { (excluding } 1 \text { value }\end{array}$} & NS & $P<0 \cdot 10$ & NS & NS & NS & NS \\
\hline & ** & * & ** & NS & * & *) \\
\hline
\end{tabular}


Table 4. Degradation by A. bisporus of killed ${ }^{14} \mathrm{C}$-labelled bacteria, glucose and cellulose

Cultures were grown with killed ${ }^{14} \mathrm{C}$-labelled bacteria as sole carbon and nitrogen source (control), unlabelled killed bacteria with added $\left[{ }^{14} \mathrm{C}\right]$ glucose, or unlabelled killed bacteria with added $\left[{ }^{14} \mathrm{C}\right]$ cellulose, in basal salts liquid medium. Values for time to degradation (presented in d) are means of four replicate samples for each treatment.

\begin{tabular}{|c|c|c|c|c|c|c|}
\hline \multirow[b]{2}{*}{ Treatment } & \multirow[b]{2}{*}{ Mean } & \multirow[b]{2}{*}{ Median } & \multirow{2}{*}{$\begin{array}{c}\text { Lower } \\
\text { quartile }\end{array}$} & \multirow{2}{*}{$\begin{array}{l}\text { Inter- } \\
\text { quartile } \\
\text { range }\end{array}$} & \multicolumn{2}{|c|}{$\begin{array}{l}\text { Percentage } \\
\text { degradation }\end{array}$} \\
\hline & & & & & Day 51 & Limiting \\
\hline Control & $15 \cdot 8$ & $15 \cdot 2$ & $12 \cdot 1$ & $10 \cdot 0$ & 37.9 & $38 \cdot 8$ \\
\hline Glucose & $13 \cdot 0$ & $12 \cdot 5$ & $10 \cdot 1$ & $6 \cdot 6$ & $37 \cdot 1$ & $37 \cdot 3$ \\
\hline Cellulose & $13 \cdot 7$ & $14 \cdot 5$ & 8.6 & 14.9 & $9 \cdot 1$ & $10 \cdot 0$ \\
\hline SED ( 9 d.f. $)$ & 0.75 & 0.76 & 0.62 & $0 \cdot 61$ & 4.98 & $5 \cdot 16$ \\
\hline Significance ${ }^{\dagger}$ & * & $*$ & $* * *$ & $* * *$ & $* * *$ & $* * *$ \\
\hline
\end{tabular}

SED, standard error of the difference between two means. $\dagger *, P<0.05 ; * * *, P<0.001$.

Table 5. Degradation of killed ${ }^{14} \mathrm{C}$-labelled bacteria added to unsterile compost (control), unsterile compost with A. bisporus, or sterile compost with A. bisporus

Values for time to degradation (presented in d) are means of four replicate samples for each treatment.

\begin{tabular}{|c|c|c|c|c|c|c|c|}
\hline \multirow{2}{*}{$\begin{array}{l}\text { Compost } \\
\text { treatment }\end{array}$} & \multirow{2}{*}{$\begin{array}{l}\text { Inoculation } \\
\text { with } \\
\text { A. bisporus }\end{array}$} & \multirow[b]{2}{*}{ Mean } & \multirow[b]{2}{*}{ Median } & \multirow{2}{*}{$\begin{array}{l}\text { Lower } \\
\text { quartile }\end{array}$} & \multirow{2}{*}{$\begin{array}{l}\text { Inter- } \\
\text { quartile } \\
\text { range }\end{array}$} & \multicolumn{2}{|c|}{$\begin{array}{l}\text { Percentage } \\
\text { degradation }\end{array}$} \\
\hline & & & & & & Day 64 & Limiting \\
\hline Unsterile & - & $4 \cdot 7$ & 4.5 & $2 \cdot 4$ & $6 \cdot 0$ & $27 \cdot 7$ & $27 \cdot 9$ \\
\hline Unsterile & + & $5 \cdot 6$ & 4.9 & $2 \cdot 5$ & $11 \cdot 0$ & $28 \cdot 4$ & $29 \cdot 3$ \\
\hline Sterile & + & $12 \cdot 0$ & $13 \cdot 0$ & $6 \cdot 6$ & $16 \cdot 4$ & $26 \cdot 6$ & $27 \cdot 8$ \\
\hline SED $(9$ d.f. $)$ & & 0.91 & 1.31 & $0 \cdot 57$ & $1 \cdot 38$ & $2 \cdot 02$ & 1.88 \\
\hline Significance $\dagger$ & & $* * *$ & $* * *$ & $* * *$ & *** & NS & NS \\
\hline
\end{tabular}

SED, standard error of the difference between two means. $\dagger$ NS, Not significant; ***, $P<0 \cdot 001$.

tures: total bacterial degradation in cultures containing additional cellulose was less than that for the control flasks containing bacteria alone, and it took place somewhat faster. The degradation of bacteria when additional glucose was incorporated was slower than that in the control cultures containing bacteria alone and it was estimated that some further degradation took place after day 49 with this treatment.

The proportion of labelled $\mathrm{C}$ degraded was much lower from the unlabelled bacteria plus $\left[{ }^{14} \mathrm{C}\right]$ cellulose treatment than from the control $\left({ }^{14} \mathrm{C}\right.$-labelled bacteria) and unlabelled bacteria plus $\left[{ }^{14} \mathrm{C}\right]$ glucose-enriched treatments (Table 4). Degradation as determined by the limiting value was almost complete by day 51 when sampling was terminated. The rate of uptake of labelled glucose was faster than that for labelled bacteria in the control (a smaller lower quartile and a shorter interquartile range). The uptake of labelled cellulose was only $10 \%$, so that the treatment summary for label uptake is of little consequence, though it should be noted that the inter-quartile range was greater than for the other two treatments. This suggests that the degradable carbon in the cellulose is less readily available than from the other two sources.

The micro-organisms present in compost can also degrade components of bacteria added to compost. Summary statistics of time to degradation of ${ }^{14} \mathrm{C}$-labelled bacteria in unsterile compost (control), in unsterile compost with $A$. bisporus, or in sterile compost with $A$. bisporus are presented in Table 5. By day 64 all treatments had effectively reached their limiting levels of degradation, which were not significantly different. On the unsterile compost half the degradable carbon had been released as $\mathrm{CO}_{2}$ within about $6 \mathrm{~d}$, but thereafter the rate slowed down more quickly when $A$. bisporus was present (note the longer inter-quartile range). The process of degradation was much slower for the sterile compost, though the same percentage degradation was achieved by day 64 (Table 5).

$A$. bisporus and the compost microflora were able to mineralize biomass produced in situ where label was incorporated into the microbial biomass by composting 
Table 6. Effect of adding A. bisporus to sterile and unsterile compost on the degradation rates of labelled ${ }^{14} \mathrm{C}$ incorporated into the indigenous microbial biomass during composting

\begin{tabular}{|c|c|c|c|c|c|}
\hline \multirow{2}{*}{$\begin{array}{l}\text { Compost } \\
\text { treatment }\end{array}$} & \multirow{2}{*}{$\begin{array}{l}\text { Inoculation } \\
\text { with } \\
\text { A. bisporus }\end{array}$} & \multirow[b]{2}{*}{ Replicates } & \multicolumn{2}{|c|}{$\begin{array}{l}\text { Percentage } \\
\text { degradation }\end{array}$} & \multirow{2}{*}{$\begin{array}{c}\text { Daily percentage } \\
\text { degradation } \\
\text { days } 49-98\end{array}$} \\
\hline & & & Day 49 & $(\log i t) \dagger$ & \\
\hline 1. Unsterile & - & 6 & $10 \cdot 3$ & $(-2 \cdot 17)$ & 0.099 \\
\hline 2. Sterile & - & 2 & $6 \cdot 1$ & $(-2 \cdot 74)$ & $0 \cdot 044$ \\
\hline 3. Unsterile & + & 10 & $15 \cdot 2$ & $(-1.79)$ & $0 \cdot 118$ \\
\hline 4. Sterile & + & 6 & $13 \cdot 5$ & $(-1.95)$ & $0 \cdot 087$ \\
\hline $\begin{array}{l}\text { SED } \neq \text { (av.) } \\
\text { (20 d.f.) }\end{array}$ & & & & $\begin{array}{l}0 \cdot 285 \\
0 \cdot 403\end{array}$ & $\begin{array}{l}0 \cdot 024 \\
0 \cdot 034\end{array}$ \\
\hline Significance & & & & $* \S$ & $(P<0 \cdot 10)$ \\
\hline
\end{tabular}

$\dagger$ Logit $(X \%)=\log _{\mathrm{e}}[x /(100-x)]$.

$\ddagger$ SED, standard error of the difference between two means. SEDS vary with the replication of the treatments being compared; the first value is appropriate for comparing any pair of treatments 1,3 and 4 , while the second applies to comparisons of treatment 2 with any other. $\S *, P<0 \cdot 05$.

rather than added as killed bacteria. The effect of adding $A$. bisporus to sterile and unsterile labelled compost produced in this manner is shown in Table 6 . The variability between samples without $A$. bisporus was considerably less than that where the mushroom was present. In the latter case the percentage degradation was greater on day 49 for cultures containing $A$. bisporus and the rate of degradation thereafter was greater, though not significantly so. Differences between sterile and unsterile composts were less marked: the difference in variability would suggest that differences between composts without $A$. bisporus present are important.

\section{Discussion}

This is the first study to produce quantitative data to show that $A$. bisporus can mineralize (biodegrade) dead and live bacteria in vivo and in vitro, validating previous evidence (Fermor \& Wood, 1981; Grant et al., 1984; Barron, 1988; Rainey, 1989) of the bacteriolytic abilities of $A$. bisporus. The mineralization process is efficient, as evidenced by the release of $>20 \%$ of total radiolabel in the compost as ${ }^{14} \mathrm{CO}_{2}$, and confirms earlier suggestions that microbial biomass might be significant in the nutritional strategy of $A$. bisporus (Sparling et al., 1982; Fermor, 1988). The total microbial biomass in commercial mushroom compost at the end of composting was estimated as $9.2 \mathrm{mg}$ carbon ( $\mathrm{g}$ dry wt compost) $)^{-1}$ (Sparling et al., 1982). This represents approximately 2\% of the compost dry weight assuming that microbial biomass contains $50 \%(\mathrm{w} / \mathrm{w})$ carbon. The weight of $A$. bisporus mycelium in fully colonized compost has been estimated, using extracellular laccase activity as a growth marker, to be 50-125 mg (g compost) ${ }^{-1}$ (Wood, 1979). The mean ratio of mycelium dry weight to fruitbody dry weight was $1.78: 1$, giving a total $A$. bisporus biomass of approximately $137 \mathrm{mg} \mathrm{g}^{-1}$. If $A$. bisporus decomposes a high proportion of the compost microbial biomass, as indicated by the results reported here, assuming that $50 \%$ of the biomass weight was lost through respiration as $\mathrm{CO}_{2}$, then the maximum contribution of microbial biomass to the $A$. bisporus biomass would be less than $10 \%$. This means that $A$. bisporus probably obtains the bulk of its carbon nutrition from the plant polymers within straw. However, the nitrogen content of the microbial biomass is high, and since micro-organisms will also concentrate minerals during composting this biomass could act as a concentrated source of nitrogen and minerals.

It is possible to manipulate microbial species diversity and populations in compost by both physical and chemical means; thus stimulation of $A$. bisporus mycelium growth may be attainable by encouraging the growth of beneficial micro-organisms.

It is not yet known whether there is any direct relationship between the quantity of microbial biomass in a compost and the quantity of mushroom mycelium that a compost will support. The lower mushroom yields obtained from substrates produced by accelerated composting techniques (Smith, 1983) might be attributable to the lower microbial biomass present or to less degradation of the lignocellulosics. An understanding of the nutritional relationship between white-rot basidiomycetes and other micro-organisms in solid substrates may help to answer the question why some basidiomycetes can successfully colonize uncomposted lignocellulosic substrates whilst others require lignocellulose to be considerably degraded. There have been no studies to determine whether Lentinula, Pleurotus or Volvariella (the other major cultivated fungi) can utilize microbial 
biomass in wood, wheat straw or rice straw/cotton waste respectively. These three basidiomycetes can successfully colonize uncomposted materials. For example, Lentinula colonizes wood which has a $\mathrm{C}: \mathrm{N}$ ratio in excess of $100: 1$. It is possible that the nitrogen supply for mycelial growth of these fungi comes from primary microbial colonization of the felled timber and the microorganisms present in this environment may include diazotrophs.

The bacteriolytic enzyme system produced by $A$. bisporus could have at least two roles. One is to act as a nutrient-releasing system to obtain carbon, nitrogen and minerals from deposits concentrated within the microbial biomass. The ability to efficiently release such nutrients from microbial biopolymers in a complex phenolic-rich environment may be one of the factors selecting for growth of $A$. bisporus mycelium. It would be of interest to determine the growth efficiency of a range of soil micro-organisms to mineralize microbial biopolymers from such substrates.

Another possible role for the lytic and oxidative enzymes of $A$. bisporus could be to act as part of an antimicrobial system. $A$. bisporus mycelium growing in compost produces a large quantity of fungal biomass. This biomass would be an ideal nutritional source for competitive micro-organisms in this habitat. However A. bisporus appears to suffer little microbial predation in this substrate.

These studies have shown that $A$. bisporus possesses an efficient bacteriolytic system in its commercial growth substrate, composted wheat straw. Further investigations are in progress to characterize the individual enzyme activities responsible for this system and to determine the regulation of their production.

The skilful technical assistance of Sarah Moult is gratefully acknowledged. The authors acknowledge valuable discussions with J. M. Whipps and J. M. Lynch in the preparation of this manuscript.

\section{References}

ATKEY, P. T. \& WooD, D. A. (1983). An electron microscopy study of wheat straw composted as a substrate for the cultivation of the edible mushroom (Agaricus bisporus). Journal of Applied Bacteriology 55, 293-304.

Barron, G. L. (1988). Microcolonies of bacteria as a nutrient source for lignicolous and other fungi. Canadian Journal of Botany 66, 25052510.

Brain, P. \& Butler, R. (1988). Cumulative count data. Genstat News Letter 22, 38-45.

ElLIOTT, T. J. (1985). Spawn-making and spawns. In The Biology and Technology of the Cultivated Mushroom, pp. 131-139. Edited by P. B. Flegg, D. M. Spencer \& D. A. Wood. Chichester: Wiley.

FERMOR, T. R. (1983). Fungal enzymes produced during degradation of bacteria. Transactions of the British Mycological Society 80, 357-360.

FERMOR, T. R. (1988). Significance of micro-organisms in the composting process for cultivation of edible fungi. In Treatment of Lignocellulosics with White Rot Fungi, pp. 21-30. Edited by F. Zadrazil \& P. Reiniger. Amsterdam: Elsevier Applied Science.
Fermor, T. R. \& Grant, W. D. (1985). Degradation of fungal and actinomycete mycelia by Agaricus bisporus. Journal of General Microbiology 131, 1729-1734.

FERMOR, T. R. \& WoOD, D. A. (1981). Degradation of bacteria by $A$. bisporus and other fungi. Journal of General Microbiology 126, 377387.

Fermor, T. R., Randle, P. E. \& Smith, J. F. (1985). Compost as a substrate and its preparation. In The Biology and Technology of the Cultivated Mushroom, pp. 81-109. Edited by P. B. Flegg, D. M. Spencer \& D. A. Wood. Chichester: Wiley.

Grant, W. D., Fermor, T. R. \& Wood, D. A. (1984). Production of bacteriolytic enzymes and degradation of bacterial cell walls during growth of Agaricus bisporus on Bacillus subtilis. Journal of General Microbiology 130, 761-769.

Grant, W. D., Rhodes, L. L., Prosser, B. A. \& Asher, R. A. (1986). Production of bacteriolytic enzymes and degradation of bacteria by filamentous fungi. Journal of General Microbiology 132, 2353-2358.

JENKINSON, D. S. (1981). The fate of plant and animal residues in soil. In The Chemistry of Soil Processes, pp. 505-561. Edited by D. J. Greenland \& M. H. B. Hayes. Chichester: Wiley.

Kirk, T. K., ConNors, W. J., Bleam, R. D., Hackett, W. F. \& ZEIKUS, J. G. (1975). Preparation and microbial decomposition of synthetic $\left[{ }^{14} \mathrm{C}\right]-$ lignins. Proceedings of the National Academy of Sciences of the United States of America 72, 2515-2519.

KirK, T. K., Schultz, E., Connors, W. J., Lorenz, L. F. \& Zeikus, J. G. (1978). Influence of cultural parameters on lignin metabolism by Phanerochaete chrysosporium. Archives of Microbiology 117, 277285.

Piggot, P. J. (1975). Characterization of a cym mutant of Bacillus subtilis. Journal of General Microbiology 89, 371-374.

RAINEY, P. B. (1989). A new laboratory medium for the cultivation of Agaricus bisporus. New Zealand Natural Sciences 16, 109-112.

RandLE, P. E. (1974). Composts. In Report of the Glasshouse Crops Research Institute, 1973, pp. 82-84.

ROBERTS, G. C. (1985). Lignin biodegradation and aromatic metabolism by the edible mushroom, Agaricus bisporus. $\mathrm{PhD}$ thesis, University of Kent at Canterbury.

Ross, G. J. S. (1987). MLP Maximum Likelihood Program. Oxford: Numerical Algorithms Groups Ltd.

Ross, R. C. \& HARRIS, P. J. (1983). The significance of thermophilic fungi in mushroom compost preparation. Scientia Horticulturae 20, 761-770.

SMITH, J. F. (1983). The formulation of mixtures suitable for economic short duration mushroom composts. Scientia Horticulturae 19, 65-78.

SMITH, J. F. \& WoOD, D. A. (1990). Cultivation of edible fungi on plant residues. In Advances in Biological Treatments of Lignocellulosic Materials, pp. 297-310. Edited by M. P. Coughlan, \& M. T. Amaral Collaço, London: Elsevier Applied Science.

Sparling, G. P., Fermor, T. R. \& Wood, D. A. (1982). Measurement of the microbial biomass in composted wheat straw, and the possible contribution of the biomass to the nutrition of Agaricus bisporus. Soil Biology and Biochemistry 14, 609-611.

Straatsma, G., Gerrits, J. P. G., Augustijn, M. P. A. M., op Den Camp, H. J. M., Vogels, G. D. \& van Griensven, L. J. L. D. (1989). Population dynamics of Scytalidium thermophilum in mushroom compost and stimulatory effects on growth rate and yield of Agaricus bisporus. Journal of General Microbiology 135, 751-759.

Treschow, C. (1944). Nutrition of the cultivated mushroom. Dansk Botanisk Arkiv 11, 1-180.

WAIN, D. I. (1981). Investigation of the nutrition of the mushroom Agaricus bisporus (Lang) Sing. in compost. $\mathrm{PhD}$ thesis, University of Bath.

WOOD, D. A. (1979). A method for estimating biomass of Agaricus bisporus in a solid substrate, composted wheat straw. Biotechnology Letters 1, 255-260.

WOOD, D. A. \& FERMOR, T. R. (1985). Nutrition of A. bisporus. In The Biology and Technology of the Cultivated Mushroom, pp. 43-61. Edited by P. B. Flegg, D. M. Spencer \& D. A. Wood. Chichester: Wiley.

Wood, D. A. \& SMITH, J. F. (1987). The cultivation of mushrooms. In Essays in Agricultural and Food Microbiology, pp. 309-343. Edited by J. R. Norris \& G. L. Pettipher. Chichester: Wiley. 